https://doi.org/10.15407/socium2020.02.110

UDC [316.4.051.6:331.535]:159.947.5-021.414

Nagorniak K.M., Analytics Manager, Sociologist, Academy DTEK, 3, Dorohozhytska Str., Kyiv, 04119, Ukraine, email: nagornyaken@dtek.com

\title{
GENERATION X, Y AND Z VALUES IN UKRAINE ${ }^{1}$
}

The paper presents findings of a survey into values of different generations conducted by Academy DTEK jointly with hh.ua|grc During two months of 2019 we polled 2,182 visitors of the Ukrainian Job portal hh.ua|grc (both job seekers and employers), followers of the survey organizers' pages in social networks (Facebook and Telegram) aged between 15 and 72. The purpose of the study was to find out the central values of young people and older generations of Ukraine. To study the values of generations, the author used Shalom Schwartz's method of ten fundamental individual values. The method was applied to three different generations. The findings of the poll enabled us to answer questions regarding values and job values of generations $X, Y$, and $Z$. What are the similarities and differences of generations, what motivates them at work, and which supervisor is more comfortable for them to work with. The outcome of this survey is a data-oriented database for Ukrainian businesses and the state and public sectors. As the survey shows, the youth upholds values related to individualistic preferences and openness to change: young people strive for new ideas, adventures, and risks and want to be creative and go their own way. The older generation holds values associated with the preservation of traditions and customs, conformity (following rules and norms), and security. Representatives of different generations need different things from their potential supervisors. For instance, Generation $Z$ feels it is essential to be able to ask their supervisor any questions they like, even if they may sound "ridiculous", and be treated as equals by their supervisor. For Generation $Y$, their supervisor must discuss professional development issues with them: their goals and expectations concerning career advancement. For Generation X, the supervisor must trust them and build a climate of mutual support and collaboration in the team.

Keywords: Generations X, Y, Z; generation values, job values, ideal supervisor.

Нагорняк К.М., менеджер-аналітик, соиіолог, Академія ДТЕК, вул. Дорогожицька, 3, Київ, 04119, Україна, email: nagornyaken@dtek.com

\section{ЦІННОСТІ ПОКОЛІНЬ Х, Y ТА Z В УКРАЇНІ}

Представлено результати дослідження цінностей різних поколінь, проведеного Академією ДТЕК спільно з hh.ua|grc. Протягом 2 місяиів 2019 р. було опитано 2182 відвідувачі украӥнського Јоb-порталу hh.иа|grс (пошукачів $i$ роботодавиів), підписників сторінок організаторів дослідження у сочіальних мережах "Facebook" та "Telegram" віком 15-72 роки.

Мета дослідження полягала в з'ясуванні основних иінностей молоді та старших поколінь Украӥни. Для вивчення цінностей поколінь було використано методику десяти базових індивідуальних иінностей Ш. Швария. Методику застосовано на трьох різних поколіннях. Результати опитування дали змогу відповісти на запитання щзодо иінностей поколінь $X, Y, Z$, у чому вони схожі, а в чому - різні, щя мотивує в роботі та з яким керівником комфортніше працювати. Результати изього дослідження є дата-орієнтованою базою для українського бізнесу, державного та громадського секторів. За результатами дослідження, молодь

\footnotetext{
${ }^{1}$ A full report of the survey entitled "Generation Formula: Values and Motives of Modern Generations" is available at https://hhcdn.ru/file/16834655.pdf. When this material is used, it is obligatory to give references to the survey organizers, Academy DTEK and hh.ua|grc.
}

(C) Nagorniak K.M., 2020 
сповідує иінності, які пов'язані з індивідуалістичними уподобаннями та відкритістю до змін - прагне до нових ідей, пригод і ризиків, має бажання бути творчою особистістю, йти своїм шляхом. Старше покоління сповідує иінності, що стосуються збереження традицій $і$ звичаїв, конформності (слідування правилам $і$ нормам) та безпеки. Представники різних поколінь мають різні запити до потенційного керівника. Для покоління $Z$ важливою є можливість ставити будь-які запитання керівнику, навіть, якщо воно може здатися "безглуздим", щоб керівник ставився до них як до рівного. Для покоління Ү важливо, щуоб керівник обговорював $з$ ним питання професійного розвитку: иілі та очікування щзодо кар'єрного зростання. Для покоління Х важливо, щоб керівник йому довіряв і створював у колективі атмосферу взаємної підтримки та співробітницчтва.

Ключові слова: покоління $X, Y, Z$, иінності поколінь, професійні ичінності, ідеальний керівник.

The topicality of the survey. A person's values remain stable over time and do not change abruptly under the influence of minor situations [1]. They will not change quickly under the effect of some routine events in one's professional, family, or political life. However, values may transform under the pressure of global life situations, making people rethink their life priorities.

First and foremost, events of one's childhood and teenage years shape the values. This period is the most crucial in forming a person's traits. However, they may evolve throughout an entire life as people do not live separately from society. Different generations have different attitudes towards life goals, surrounding environment, social groups where they spend most of their time. Among Ukrainian researchers, the topic of transformation of value orientations, youth values, and change of values among generations is well developed (A. Ruchka [2], Yu. Savelyev [3; 4], L. Sokuryanska [5] and others).

Why is it essential to study generational values? The labor market is seeing a sharp rise in the share of Millennials (Generation Y representatives). At the same time, the share of older people is growing too. In 2020, the oldest Millennials will turn 40, and they will make up over 50\% of all the workforce [6]. The labor market is starting to see young specialists coming in who may differ from the older generations in terms of their life priorities and attitudes to work, co-workers, and the supervisor.

On the one hand, employers have to revisit and change their approaches to employee onboarding, motivation to adapt to the requirements of modern times. On the other hand, they should understand universal values shared by each of the generations, which will help work with each of them more actively. In order to create a value proposition (EVP) and build a corporate culture, it is crucial to factor in both primary priorities and those characteristics of the specific generation.

The purpose of the study was to find out the central values of young people and older generations of Ukraine. The target study group was visitors of the Ukrainian job portal (job seeker and employer audience) and followers of the survey organizers' pages in social networks (Facebook and Telegram).

This article focuses on shared values of generations and their differences, professional values of young people, and the older generation, as well as characteristics of the leader (ideal supervisor in the opinion of generations). 


\section{Nagorniak K.M.}

The findings of this survey laid the foundation for a data-oriented database for Ukrainian businesses and the state and public sectors. They provide a theoretical and methodological underpinning for a more in-depth search for universal and unique generational characteristics. Based on the body of data that we managed to collect, we present our findings and welcome a discussion over generational values and preferences.

Results are not extrapolated to society as a whole because we study a separate group, namely, the audience of job seekers and employers who are users of the job search site and subscribers to the pages of the study organizers on social networks Facebook and Telegram.

Survey methodology. Between July 18 and September 18, 2019, Academy DTEK jointly with hh.ua|grc conducted their survey among visitors of the job portal (job seeker and employer audience), followers of the survey organizers' pages in social networks (Facebook and Telegram).

We collected a body of data comprising 2,182 valid questionnaire forms filled in by responders aged between 15 and 72 via an online poll (318 respondents who identified themselves as employers; the rest were job seekers, regardless of their current employment).

The hh.ua|grc base of job seekers was about 1 million participants in the period of conducting the survey. The number of registered unemployed in Ukraine for the period from January to September 2019 amounted to 799,095 people (who had the status of non-working usually reporting period) [7]. At the end of September 2019 (the period of completion of the survey), this number was 268,188 people [7].

If we compare the poll participants with the job portal audience mix during the survey period, the portal visitors' age distribution is almost commensurate to that of the responders, which means that we managed to poll a significant portion of the portal visitors (job seeker and employer audience) (Table 1).

Table 1

Age distribution of Job portal audience and survey participants

\begin{tabular}{|c|c|c|}
\hline Age, years & $\begin{array}{c}\text { Online survey participants } \\
\text { during the period } \\
18 / 07 / 19-18 / 09 / 19, \%\end{array}$ & $\begin{array}{c}\text { Audience of } \\
\text { Job-portal } \\
\text { hh.ua|grc, } \%\end{array}$ \\
\hline $15-22$ & 20 & 8 \\
\hline $23-38$ & 53 & 59 \\
\hline $39-53$ & 23 & 26 \\
\hline $54-72$ & 4 & 7 \\
\hline
\end{tabular}

The survey geography encompasses entire Ukraine except for the temporarily occupied areas: 24 regions and the city of Kyiv.

The main channels of information are a mass emailing of the online questionnaire among job seeker and employer audience of the job portal hh.ualgrc, ad banners on the website, pages of the organizers (Academy DTEK and hh.ua|grc) and partners (Charitable Foundation "Lifelover" and Municipal Institution "Kyiv Youth Center") in the social networks - Facebook and Telegram.

Survey age range. While studying the generational values, we turned to Neil Howe and William Strauss's theory. It first drew attention in 1991 when the authors published their book entitled Generations: The History of America's Future, 1584 to 2069. They showed 
that there are historical analogies between the past and modern generations: tentatively every 20 years there is a new generation being born, which has different preferences, motivations, values, etc. Specifically, it depends on the available life experience (including the collective one). There are at least four generations defined based on the birth years, which have their specific differences:

1. Generation $Z$ - tentative years of birth from $2000+$ to date.

2. Generation $\mathrm{Y}-1984-2000$.

3. Generation X - 1963-1984.

4. Generation BB (Baby Boomers) - tentative years of birth from 1943 to 1963.

There is no single opinion on how to break the population down into generations because researchers set their birth year ranges specific to a particular culture or country. For this study, we defined Generations BB, X, Y, and Z, taking into consideration historical events that may have shaped the Ukrainian generations (Table 2).

Table 2

Major events shaping generation members

\begin{tabular}{|l|}
\hline \multicolumn{1}{|c|}{$\mathbf{Z}$} \\
\hline - Tentative birth \\
years: 1997 to date \\
Age: 15-22 \\
- Orange Revolution \\
and Revolution of \\
Dignitiy, Annexation \\
of Crimea, beginning \\
of the military \\
mobilization due to \\
war in Eastern \\
Ukraine. \\
- IT development, \\
period of economic \\
growth and \\
stabilization, hryvnia \\
freefall. \\
- Web 2.0 and mobile \\
technology \\
development \\
\end{tabular}

\begin{tabular}{|l|}
\hline \multicolumn{1}{|c|}{ Y } \\
\hline - Tentative birth \\
years: 1981-1996 \\
Age: 23-38 \\
- Perestroika (political \\
and economic \\
restructuring of the \\
Soviet Union), \\
terrorism and wars, \\
Chernobyl Disaster. \\
- Soviet Union \\
collapse; \\
Tumultuous '90s, \\
independence \\
declaration by \\
Ukraine and start of \\
privatization, global \\
financial crisis. \\
- Development of \\
mobile \\
communications and \\
Internent, IT, social \\
networks, digital \\
media \\
\hline
\end{tabular}

\begin{tabular}{|l|}
\hline \multicolumn{1}{|c|}{$\mathbf{X}$} \\
\hline - Tentative birth \\
years: 1966-1980 \\
Age: 39-53 \\
- End of Cold War, \\
start of Afghanistan \\
War. \\
- Perestroika (political \\
and economic \\
restructuring of the \\
Soviet Union), \\
heyday of collective \\
farming, political \\
crisis. \\
- Demographic \\
regression. \\
- Gender changes in \\
the labor market and \\
shift in social roles. \\
- Advent of Internet \\
\end{tabular}

\begin{tabular}{|l|}
\hline \multicolumn{1}{|c|}{ BB } \\
\hline - Tentative birth \\
years: 1946-1965 \\
Age: 54-72 \\
- Post-war \\
reconstruction, Thaw \\
and Cold War, times \\
of goods shortage. \\
- Demographic \\
explosion. \\
- Moon landing. \\
- Popularity of rock \\
music and youth \\
subcultures (hippies). \\
- Evolution of social \\
and political views in \\
the society \\
\end{tabular}

Although this conceptual scheme of generational division is used, there is a considerable research tradition that has begun from K. Mannheim [8].

Individual values: Theoretical model. In order to measure values, we turned to Shalom H. Schwartz's method. The Schwartz theory of fundamental values identifies ten broad personal values, which are differentiated by the underlying goal or motivation [9].

According to the methodology of Shalom Schwartz, values form a circular motivational continuum. In contradiction to existing classifications of values, this approach determines the 
structure of motivation factors. Based on empirical research conducted in 60 countries of the world, in which more than 100 thousand people participated, Schwartz's theory claims that values are tasks that exist outside the situation and serve the interests of individuals or groups and represent one of ten human motivations.

The individual values are placed on the motivational continuum (circle) based on the following principle: neighboring values are the most compatible, and the opposite ones conflict with one another. Compatible values complement each other as people want to satisfy their own needs and seek social integration. However, some values may conflict with one another. When such conflicting values meet within one person, he/she may feel unsatisfied, unfulfilled.

For the sake of convenience, we grouped Schwartz's ten fundamental individual values into four motivational factors:

1. Openness to change (Self-Direction and Stimulation).

2. Self-enhancement (Achievement and Power).

3. Conservation (Tradition, Security, and Conformity).

4. Self-transcendence (Benevolence and Universalism).

Hedonism lies between the Openness to Change and Self-Enhancement value groups.

In the questionnaire, the scale questions were suggested as follows. The responders were offered to evaluate how accurately each of the statements describes a person similar to themselves. Each of the statements refers to specific values responders tried on and rated on a 6-point scale - from 1 being 'not like me at all' to 6 'very much like me'. Below is a list of these values (Table 3 ).

Ten fundamental individual values according to S. Schwartz

Table 3

\begin{tabular}{|l|l|}
\hline \multicolumn{1}{|c|}{ Values } & \multicolumn{1}{c|}{ Statement: For this person, it is crucial to... } \\
\hline Self-direction & Think up new ideas, be creative, go his/her own way \\
\hline Power & Be rich, have a lot of money and expensive things \\
\hline Security & Live in safety, he/she avoids everything that may pose a danger \\
\hline Hedonism & Have a good time, indulge himself/herself \\
\hline Benevolence & Do something good for society \\
\hline Achievement & Be very successful for people around to know about his/her achievements \\
\hline Stimulation & Have adventures and take risks, he/she wants to have a life full of breath-taking events \\
\hline Conformity & Always behave properly, avoid doing anything that people would say is wrong \\
\hline Universalism & Look after the environment and nature \\
\hline Tradition & Follow traditions and customs handed down by his/her family or religion \\
\hline
\end{tabular}

Generational values: What are our similarities? Of the top five values, the following are found to be common to all generations (Table 4):

- Self-direction (think up new ideas, be creative, go one's way);

- Benevolence (do something good for the society);

- Universalism (look after the environment and nature).

Shared Universalism and Benevolence values reflect global trends, which indicate that Generations $\mathrm{Y}$ and $\mathrm{Z}$ are focused on looking after the society and the environment. Deloitte's research suggests that the Generation $\mathrm{Y}$ and $\mathrm{Z}$ lists of priorities are topped not by having children, owning a home, and other conventional adult' success markers', but by traveling 
around the world (57\% of responders) and benefiting the society (46\% of responders) [6]. The aspiration to make the world a better place shows up not only in the issues of climate change and environmental pollution but also in the choice of consumer goods and services as well as employers.

Table 4

Top 5 individual generational values

\begin{tabular}{|c|c|c|c|}
\hline Top values & Generation Z & Generation Y & Generation X \\
\hline Rated No. 1 & Self-direction & Benevolence & Benevolence \\
\hline 2 & Benevolence & Universalism & Self-direction \\
\hline 3 & Hedonism & Self-direction & Universalism \\
\hline 4 & Universalism & Hedonism & Security \\
\hline 5 & Achievement & Achievement & Tradition \\
\hline
\end{tabular}

Generational values: What are our differences? Looking into the values of the poll participants, we found that Generations $\mathrm{Y}$ and $\mathrm{Z}$ are widely different from the older Generation $X$ in terms of life priorities they choose.

Generation $\mathrm{Z}$ values most Self-Direction - being able to think up new ideas, be creative, go one's own way. Representatives of Generations $\mathrm{Y}$ and $\mathrm{X}$ place importance on Benevolence - desire and aspiration to do something good and useful for society.

Such values as Stimulation and Hedonism - desire to have breath-taking adventures, indulge oneself - are more often characteristic of the younger Generations $\mathrm{Z}$ and $\mathrm{Y}$.

At the same time, the older Generation $X$ upholds Tradition and Universalism.

The values' least characteristic of Generations $\mathrm{Y}$ and $\mathrm{X}$ is Power. Furthermore, for Generation Z, the least characteristic values are Tradition and Conformity.

After placing the generations' scores on the motivational continuum, we compared the factor-based value groups. Thus, one can see that:

For Generation Z, such value groups as Openness to Change, Self-Enhancement, and Self-Transcendence are more characteristic, and Conservation is less characteristic. The Generation $\mathrm{Y}$ values mix is the same, but they attach less importance to Openness to Change and more importance to Conservation.

Generation $\mathrm{X}$ representatives uphold different values than the younger generation: Self-Transcendence and Conservation (Chart 1).

As the comparison between, for example, Openness to Change and Conservation suggests, there is a possibility of a conflict between the generations.

The youth strives for self-direction, new ideas, adventures, and risks, whereas the older generation seeks conservation of traditions and customs, conformity, and security. Such value groups may not be congruent and conflict with each other as it is more challenging to be open to something new while observing traditions and, at the same time, following already set norms and rules.

What does it tell us? In practice, such differences in values may lead to disagreements in understanding working issues and making decisions when the supervisor and his/her subordinate are representatives of generations with conflicting values.

For instance, decisions to make changes in the company may be perceived by the older generation as something that disrupts a stable and smoothly running system of processes. At 


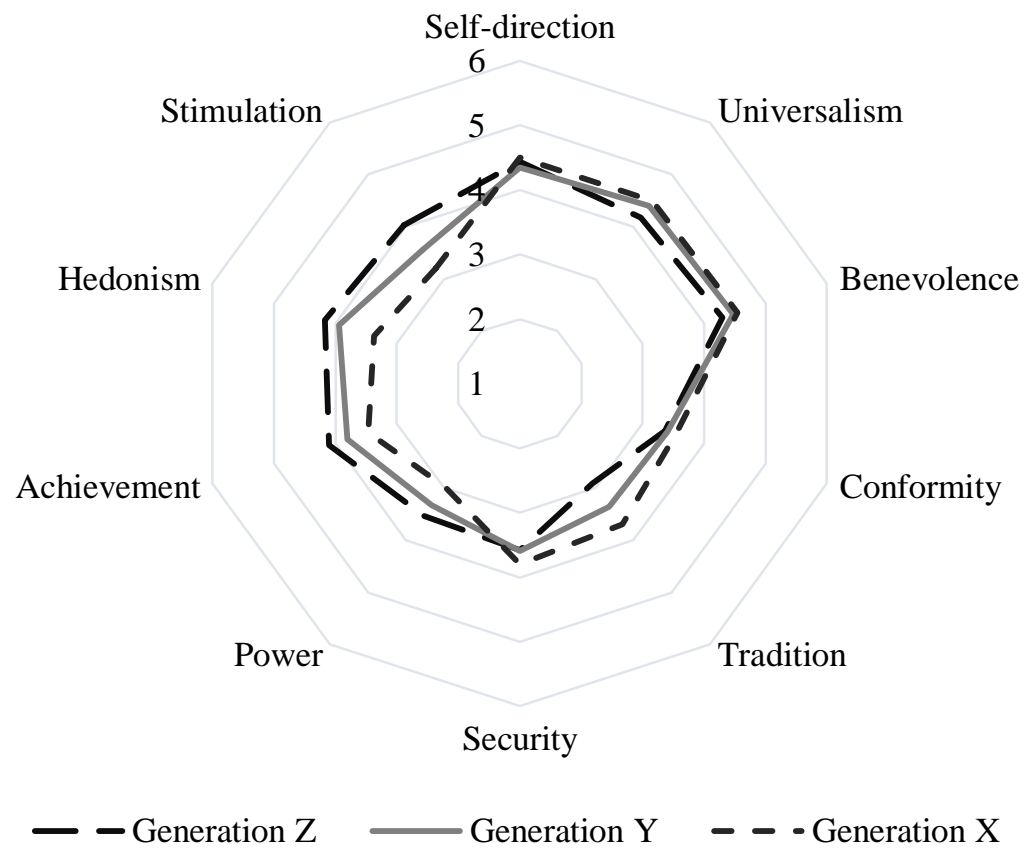

Chart 1. Generational values

the same time, the younger generation will more readily accept changes and quite enthusiastically get engaged in the new working processes.

Employment of the generations: What is essential to the generations in choosing the job? As part of the survey, we proposed the responders to assess the importance of several job-related criteria ${ }^{2}$.

The list of choice options included 27 items, of which 15 are presented below:

We separately looked into the top ten most essential and most frequently mentioned job criteria and the five most rarely chosen criteria. The ten common and most frequently mentioned factors were split into the following categories of criteria most valued by the poll participants (Chart 2):

- Financial criteria: income level (for the overwhelming majority of responders);

- Fulfillment criteria: learning and career advancement opportunities, personal development prospects;

- Professional environment criteria: team, management, professional environment;

- Security and stability criteria: official employment status;

- Time criteria: maintaining a work-life balance, convenient work schedule.

\footnotetext{
${ }^{2}$ The question put to the responders read as follows: "Which of the things listed below do you find the most important in your job for you personally" (You may choose up to 8 most important items).
} 


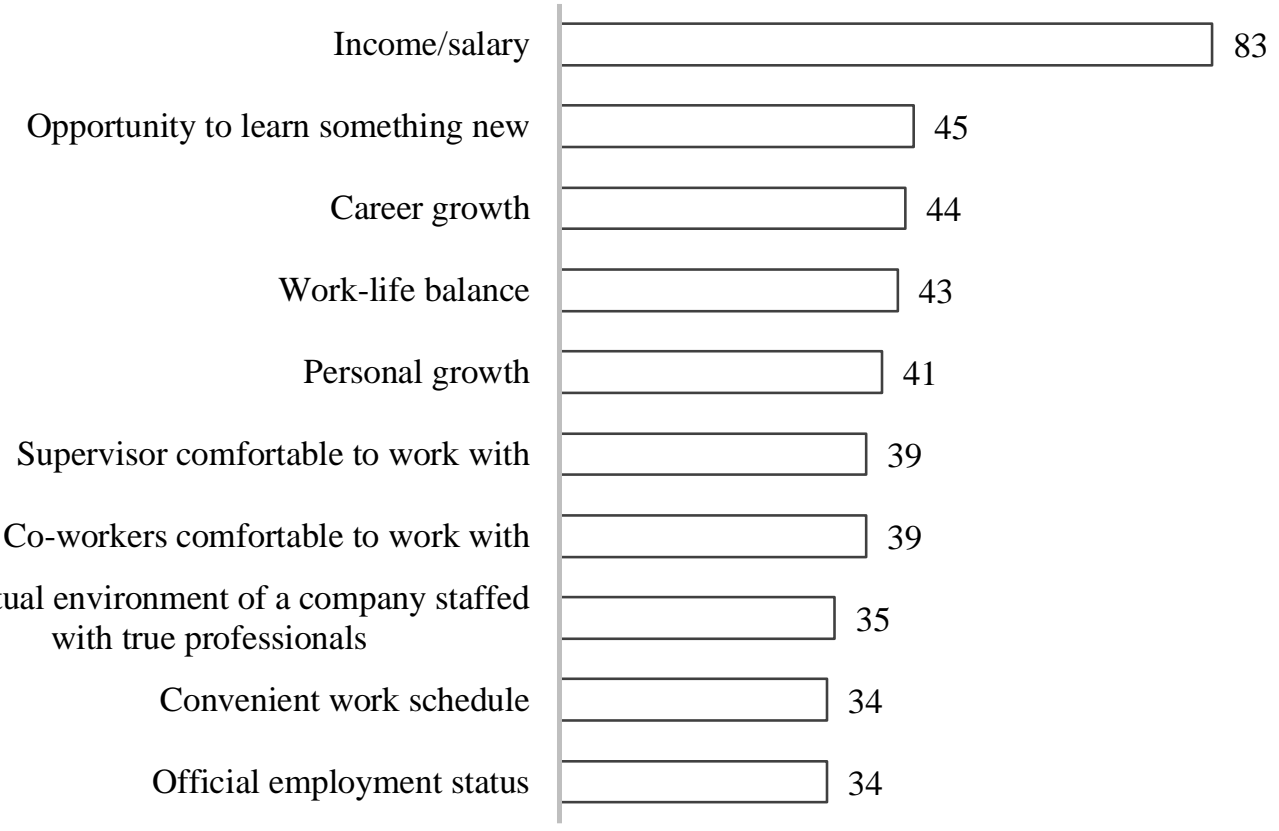

Chart 2. Top 10 job values, all generations, \%*

* The sum is not equal to $100 \%$ because the responders could choose several options.

The five least critical job-related criteria for the survey participants were split into the following categories (Chart 3):

- Company status advantages: social responsibility, international relations (specifically, cooperation with foreign specialists);

- Organizational working issues: no overtime or minimum overtime hours, a safe working environment, and paid leave.

Communicating and working with foreign co-workers

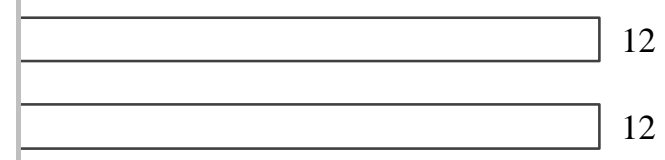

Company's ethics, social responsibility

Fixed working hours

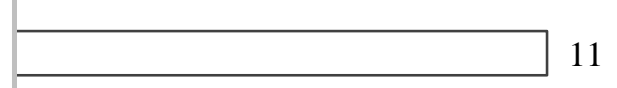

Safe working environment

Number of vacation days

\section{9}

Chart 3. Irrelevant job values, all generations, \%*

* The sum is not equal to $100 \%$ because the responders could choose several options. 


\section{Nagorniak K.M.}

The most valuable job-related factors for Generation $\mathrm{Z}$ were found to be:

- Income/pay - 79\%;

- Career advancement and personal growth $-64 \%$ and 51\%, respectively;

- Opportunity to learn something new $-52 \%$;

- Colleagues comfortable to work with $-43 \%$.

Interestingly, the youth aged between 15 and 22, while describing items essential in job evaluation, ranks the pragmatic goals related to one's professional and personal development first (after salary).

We found that of principal importance to Gen Zers (or most often selected by this generation as compared to the others) are:

- Career advancement and personal growth;

- Convenient work schedule (being able to choose work hours);

- Prestigious job;

- Being able to carry out diverse tasks;

- Communication with foreign co-workers (which sets Gen Zers far apart from representatives of the other generations).

Overall, Gen Zers and Gen Yers seem to be the most pragmatic and purposeful among all the generations studied. This pragmatic nature shows up in their aspiration to develop professional skills and pursue career growth and personal development. The social environment, namely, comfort in communicating with the team, is not listed among the most crucial job values for the youth.

Generation Y primarily job values:

- Financial prospects - 84\%;

- Career growth and personal development opportunities - 50\% and 48\%, respectively;

- Opportunity to learn something new $-46 \%$;

- Professional / personal life balance $-44 \%$.

Generation $X$ representatives value most a job that:

- Provides for them financially $-82 \%$;

- Allows them to balance work and personal life $-44 \%$;

- Gives official employment status - 43\%;

- Enables them to acquire new knowledge - $41 \%$;

- Gives them moral comfort and ensures comfortable relations with the supervisor and the team $-36 \%$ and $35 \%$, respectively.

Generation $\mathrm{X}$ more rarely mentioned career prospects, personal development opportunities, and a convenient schedule. They are less focused on their professional and personal development, which is attributable to the considerable experience that they have gained, and attach more value to the personal / professional life balance. At the same time, Gen Xers are open to acquiring new knowledge, which somewhat contradicts their lack of career ambitions and personal development aspirations. We can partially explain it by the fact that Gen Xers hold the stereotype that a career is built on 'patronage'. However, they want to get new knowledge in order to keep track of technological advancement (Chart 4). 


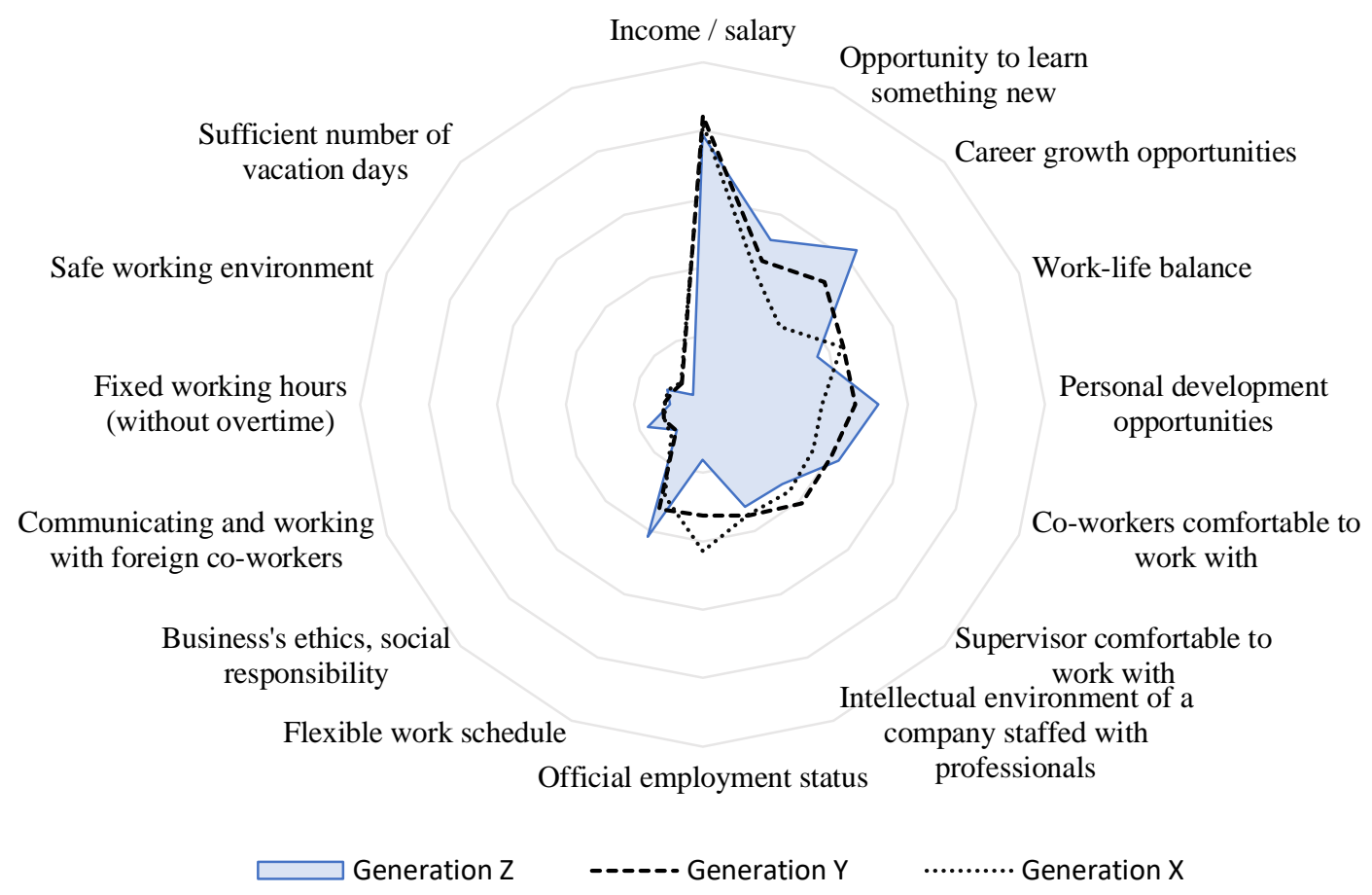

Chart 4. Job values, Generations $Z, Y$ and $X$

Ideal supervisor for the generations. In our poll, we could not help but ask the survey participants about the potential supervisor and criteria outlining his/her ideal image $(\text { Chart } 5)^{3}$.

The responders believe that their potential supervisor has to:

- Create a climate of mutual support and collaboration in the team $-81 \%$;

- Respect subordinates' opinions even if they differ from his/her own $-66 \%$;

- Share his/her knowledge - 62\%;

- Give regular feedback - 60\%;

- Trust his/her subordinates $-54 \%$.

Generation $\mathrm{Z}$ points to the need to get new knowledge from the supervisor, be able to ask any questions, and have learning and development opportunities more frequently than the others. Besides, the youth needs the supervisor to treat them as equals. For Generation Y, it is vital that the supervisor discuss professional development issues with them: their goals and expectations with regards to career advancement. For Generation X, their supervisor must trust them and create a climate of mutual support and collaboration in the team (Chart 6).

\footnotetext{
${ }^{3}$ The question put to the responders read as follows: "For me it is important that my potential supervisor ..." (You may choose up to 5 most important items).
} 
Nagorniak K.M.

Create a climate of mutual support and collaboration in the team

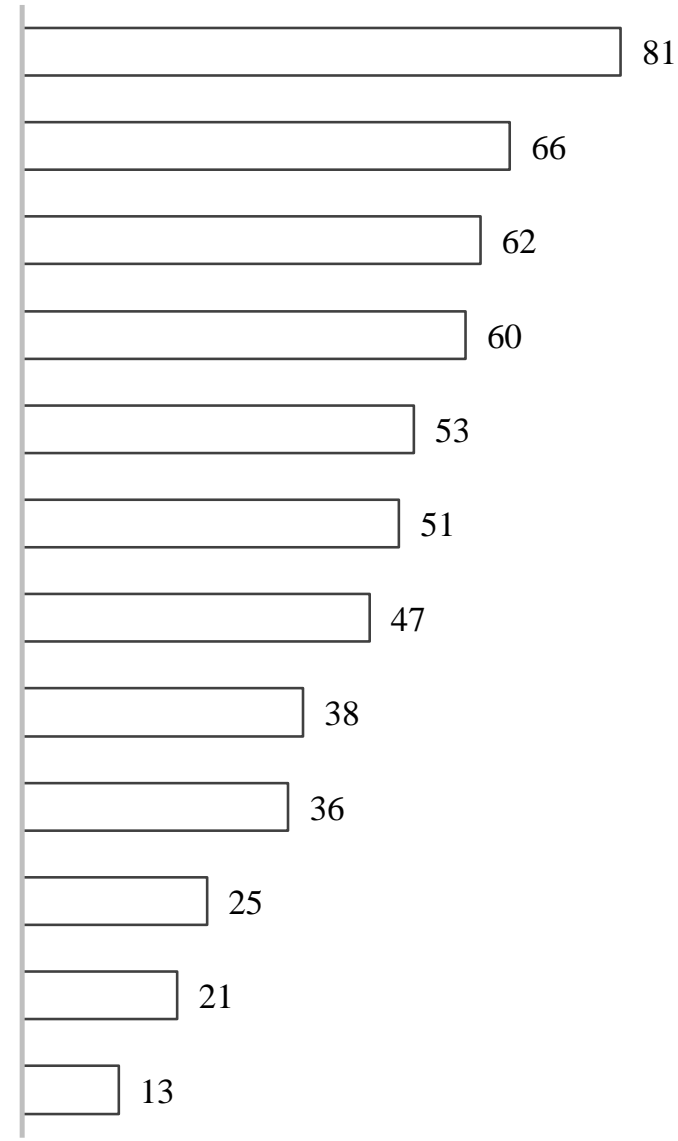

Create conditions for learning and development

Give an opportunity to ask any questions even if them may sound "ridiculous"

Discuss my career goals and expectations with

$$
\begin{aligned}
& \text { Share knowledge } \\
& \text { Sherent }
\end{aligned}
$$

Give regular feedback

Trust me

Respect subordinates' opinions, consider them even if they are different

$$
\begin{gathered}
\text { Treat me as an equal } \\
\text { Spend time on my personal development } \\
\text { Praise me, say "thank you" for achievements at } \\
\text { work } \\
\text { Be interested in my internal emotional state } \\
\text { (mood, feelings) }
\end{gathered}
$$

Chart 5. What are the attributes of an ideal supervisor, all generations, \%*

* The sum is not equal to $100 \%$ because the responders could choose several options.

By comparing the criteria relevant to the responders at work with the image of an ideal supervisor, we found a direct relationship. The responders for whom their supervisor must be a person comfortable to work with point out at the same time that an ideal supervisor for them is a person who:

- Trusts his/her subordinates;

- Gives regular feedback;

- Creates a climate of mutual support and collaboration in the team;

- Allows asking any questions even if they may be considered "ridiculous";

- Respects his/her subordinate's opinion even if it differs from his/her own.

Therefore, we found a formula for being a 'comfortable' supervisor, as indicated by the poll participants, which includes such things as trust in subordinates, feedback, the climate of support and collaboration in the team, and being able to ask any questions. 
Create a climate of mutual support and collaboration in the team

Share knowledge

Respect subordinates' opinions, consider them even if they are different

Give an opportunity to ask any question even if it may sound "ridiculous"

Create conditions for learning and development

Give regular feedback

Treat me as an equal

Trust me

Discuss my career goals and expectations with me

Spend time on my personal development

Be interested in my internal emotional state (mood, feelings)

Praise me, say "thank you" for achievements at work

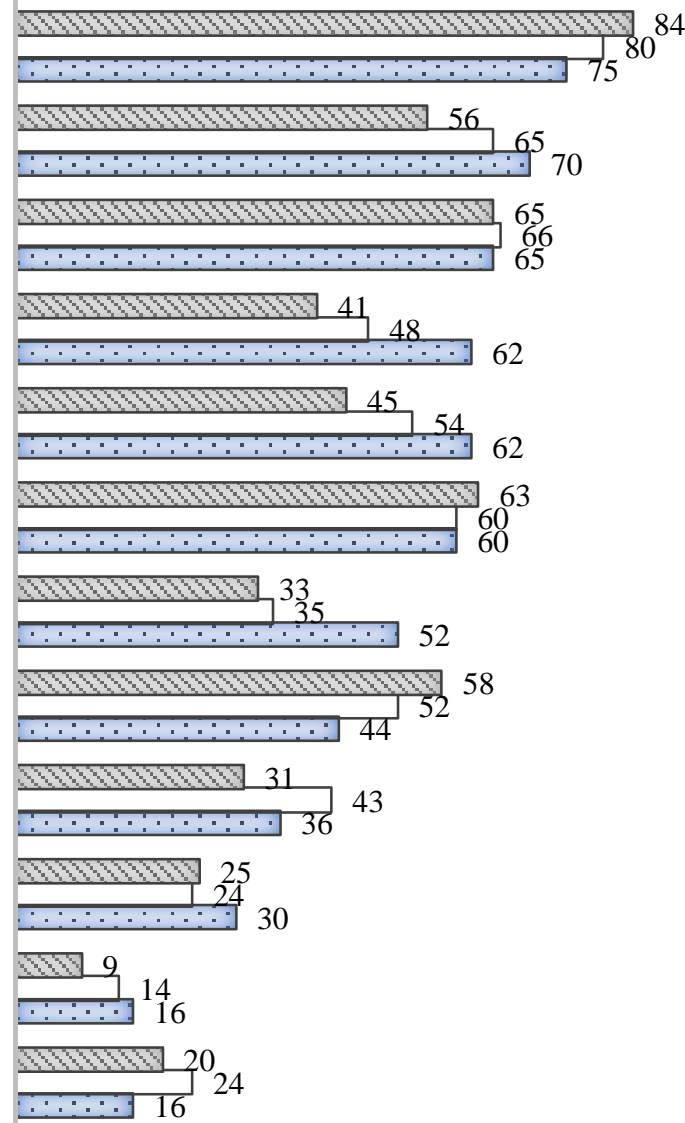

Chart 6. What are the attributes of an ideal supervisor, Generations $Z, Y$, and $X$, \%*

* The sum is not equal to $100 \%$ because the responders could choose several options.

Conclusions. Thus, this study on the example of Ukraine allows drawing the following conclusions. The youth strives for self-direction, new ideas, adventures, and risks, whereas the older generation seeks conservation of traditions and customs, conformity, and security. Such values as Stimulation and Hedonism - strive for breath-taking adventures and risks in one's life, having a good time and indulging oneself - are more characteristic of the younger Generations $\mathrm{Z}$ and $\mathrm{Y}$. At the same time, the older Generation $\mathrm{X}$ values Tradition and Universalism.

Income is the most significant job value for all the generations. Generations $\mathrm{Z}$ and $\mathrm{Y}$ rank the career growth second (which is indicative of their quite pragmatic nature) and Generation $X$ the official employment status.

Dealing with representatives of several generations, an ideal supervisor has to carry out several tasks: create a climate of mutual respect and collaboration in the team (for all), teach (for Generation Z), take part in professional development (for Generation Y), and create a climate of trust (Generation X). As the survey shows, the youth upholds values related to 


\section{Nagorniak K.M.}

individualistic preferences and openness to change: young people strive for new ideas, adventures, and risks and want to be creative and go their own way. The older generation holds values associated with the preservation of traditions and customs, conformity (following rules and norms), and security. Such values groups may not be congruent and conflict with each other as it is more challenging to be open to something new while observing traditions and, at the same time, following already set norms and rules.

The data presented provide a theoretical and methodological underpinning for a more in-depth search for universal and unique generational characteristics. Based on the body of data that we managed to collect, we propose findings of our research for discussion regarding generational values and preferences and ways how to get and keep the generations engaged and ensure smooth collaboration and efficient training within the company.

Results are not extrapolated to society as a whole because we study a separate group, namely, the audience of job seekers and employers who are users of the Ukrainian job portal and subscribers to the pages of the organizers of the study on social networks Facebook and Telegram. This single study should be confirmed with data from other target groups of job seekers in the coming years to identify such or new trends. Generations differ in their socialization in diverse social conditions, so it is essential to conduct longitudinal studies to assess the dynamics of changes under the influence of social factors.

\section{References}

1. Roccas, S., Sagiv, L. (Eds.). (2017). Values and behavior. Taking a cross-cultural perspective. https://doi.org/10.1007/978-3-319-56352-7

2. Ruchka, A., Naumova, M. (2013). Values and types of the value identification in the present-day society. In V. Vorona, M. Shulga (Eds.), Ukrainian society 1992-2013. Current state and dynamics of changes. Sociological monitoring (pp. 285-297). Kyiv: Institute of Sociology of the NAS of Ukraine [in Ukrainian]

3. Savelyev, Yu. (2016). Decomposition of value change in European societies in 1995-2008: Test of modernization model and socializa-tion hypothesis. Sociológia, 48, 3, 267-289.

4. Savelyev, Yu. (2017). Multidimensional modernity: social inclusion in assessment of social development: monograph. Kyiv: The University of Kyiv [in Ukrainian]

5. Sokurianskaia, L. (2006). Students on the path to another society: the value transition discourse. Kharkov: V.N. Karazin Kharkiv National University [in Russian]

6. Leading the social enterprise: Reinvent with a human focus. 2019 Deloitte Global Human Capital Trends. URL: https://www2.deloitte.com/content/dam/Deloitte/cz/Documents/human-capital/cz-hc-trendsreinvent-with-human-focus.pdf

7. Data on the number of registered unemployed, service provision, as well as the number of registered vacancies. State Employment Service of Ukraine. URL: https://www.dcz.gov.ua/publikaciya/ 1-dani-shchodo-kilkosti-zareyestrovanyh-bezrobitnyh-ta-nadannya-yim-poslug-takozh

8. Mannheim, K. (1952). The problem of generations. In P. Kecskemeti (Ed.), Essays on the sociology of knowledge by Karl Mannheim (pp. 276-322). London \& New York: Routledge \& Kegan Paul.

9. Schwartz, S.H. (1992). Universals in the content and structure of values: Theoretical advances and empirical tests in 20 countries. Advances in Experimental Social Psychology, 25, 1-65. http://dx.doi.org/10.1016/S0065-2601(08)60281-6

Received on 26.05.20 and updated on 20.06.20 